Western University

Scholarship@Western

Aboriginal Policy Research Consortium International (APRCi)

$7-2001$

Working Towards Regional Agreements: Recent Developments in Co-operative Resource Management in Canada's British Columbia

Cathy Robinson

Follow this and additional works at: https://ir.lib.uwo.ca/aprci

Part of the Environmental Policy Commons

Citation of this paper:

Robinson, Cathy, "Working Towards Regional Agreements: Recent Developments in Co-operative Resource Management in Canada's British Columbia" (2001). Aboriginal Policy Research Consortium International (APRCi). 197.

https://ir.lib.uwo.ca/aprci/197 


\title{
Working Towards Regional Agreements: Recent Developments in Co-operative Resource Management in Canada's British Columbia
}

\author{
CATHY ROBINSON, Australian Defence Force Academy, Australia
}

Canada's experience with 'regional agreements' has attracted considerable attention in Australia as a means by which Indigenous people can secure their native title rights to land and sea and ensure they can participate in the development and management of their homeland territories. However, regional agreements implemented in Canada thus far have often taken years to negotiate. To provide a degree of certainty for resource management and decision-making while the native title claims process is underway, Canadian governments have proceeded to establish interim resource use and management agreements with Indigenous communities. While both governments and Indigenous people stress that interim arrangements do not replace or limit the scope for future claim settlements, it is recognised that the development of such cooperative relationships will make long-lasting formal agreements easier to achieve. This paper draws on several recent examples of interim agreements that have been negotiated for the salmon fishery resource in the Skeena River catchment, and considers how these local experiences offer useful approaches for resource management and native title issues in Australia. These examples demonstrate the importance of building shared understandings of resource values and management approaches prior to cementing co-management partnerships in formal settlements. They also show some of the problems and prospects facing Indigenous peoples in their efforts to benefit from such co-management agreements.

KEY WORDS Co-management; regional agreements; native title; hybridity; cross-cultural co-operation; salmon fisheries

In Australia, the courts have established that native title is grounded in the history of Indigenous peoples, their legal systems, and their connections to their traditional lands.
Accordingly, non-Indigenous Australians are obliged to reassess some of the deep inequalities that have resulted from the long experience of colonial encounter and to consider opportunities 
for social justice and reconciliation. A key issue of contestation and uncertainty raised by Indigenous and non-Indigenous people has been how native title rights are to be effectively recognised and exercised within environmental management decision-making.

Rights to resource use and management can be understood in many ways. In this paper I consider how issues of contention between Indigenous and non-Indigenous people reflect distinctive notions of cultural landscape and identity. I identify how non-Indigenous people have imposed their notions of the New World on to Indigenous people and their territories, and prevented Indigenous people's involvement in management decision-making. But I also argue that, since the commencement of colonisation, Indigenous and non-Indigenous concepts of resources, and of each other, have changed with time and experience. A legacy of this continuing historical process has been the achievement of agreements based on negotiated interpretations of each other and the landscapes we share. An understanding of the dynamic relationships between Indigenous and non-Indigenous resource users provides a useful perspective on what aspects of co-management partnerships encourage or impede the recognition of native title rights.

Regional agreements have been seen as providing an important process and outcome for the achievement of reconciliation. Increasingly, interest has turned to the Canadian experience, where new management regimes for environments and resources have been negotiated through the comprehensive claim process. It is hoped that they will offer some guidance and principles for the establishment of regional agreements in Australia (Richardson et al., 1994). Even so, those involved in the academic or practical aspects of regional agreements note that the negotiation and implementation of such agreements is not only difficult but can often take years to negotiate (see Usher, 1996).

To provide a degree of certainty for resource management and decision-making while the native title claims process is underway,
Canadian governments have proceeded to establish interim resource use and management agreements (IMAs) with Indigenous communities. While both governments and Indigenous people stress that IMAs do not replace or limit the scope for future claim settlements, it is recognised that the development of such co-operative relationships makes long-lasting formal agreements easier to achieve. Similar to regional agreements, a key element to IMAs established thus far has been the creation of new management regimes for a range of environments and resources. Termed 'co-management', these new agreements refer to dialogue and outcomes that integrate local and state management systems in which power and responsibility are reciprocated between government and local resource users (Berkes et al., 1991; Notzke, 1995). The result is a conservation partnership that is based on the recognition that conservation objectives have to be made compatible with community agendas and aspirations.

Drawing on a range of IMAs negotiated between the governments of Canada and the Skeena River First Nations of North-west British Columbia (BC), this paper shows how distinctive and conflicting notions of landscape and cultural identity can be used to evaluate critically these interim co-management agreements. The concept of hybridity will be used to articulate different fisher groups' meanings of and relations with the Skeena River catchment and to examine the role of comanagement in negotiating how resource management agreements can be made. Examples from the Skeena demonstrate the importance of building shared understandings of resource and management values prior to cementing co-management partnerships in formal regional agreements. The analysis also provides important insights that are relevant to experiences faced by Australian communities and governments, which are currently trying to negotiate and implement resource management partnerships that reflect the essence of native title claims. 


\section{Hybrid landscapes, identities and resource management partnerships}

The concept of cultural identity is complex, as Strang $(1997,159)$ has argued, but it is essentially a multi-faceted social product. Identity is grounded in relations with others, grows through interaction with people, places and things, through forms of self-expression, and is rooted in particular places, values, family or professional involvement, and spiritual beliefs. Indigenous and non-Indigenous people construct identity in very different ways, which direct and affect their resource use practices and environmental values.

Indigenous people's notion of landscape, here termed 'country', is one that Rose has understood as a nourishing terrain: 'Country is a place that gives and receives life. Not just imagined and represented, it is lived and lived with' (Rose, 1996, 7). Country lies at the heart of Indigenous history and identity, and is expressed in local narratives and practices of resource management. Thus, Indigenous people's responsibilities to 'care for country' relate to how Indigenous people are connected to specific and regional resources and landscapes, and also indicate the basis for ethics and principles underpinning environmental management decisions and priorities (Young, 1999).

In contrast, Anderson (1995, 277) has considered how views held by white people in settler societies have constructed nature 'both against and beneath humans who were henceforth justified in treating nature as object, as background to - and instrument of human purposes'. In this view, human development is largely understood as an ascent out of nature. The result is a humanenvironment relationship that reflects, in many ways, the separation or dominance of people over the biophysical environment. Colonial constructs of the landscape not only delineate boundaries of opposition between humans and nature, but they also affect social relations between Indigenous and non-Indigenous people. Indigenous people are categorised as surviving examples of human beings who had yet to evolve the capacity to order and control the growth and reproduction of resources and the environment. Wild fauna and flora are portrayed as 'out of control', and hunter-gatherers 'are no more able to achieve mastery over their environmental resources than they are to master their own internal dispositions' (Ingold, 1994, 3 ). Not only does this raise serious concerns about the political character of such knowledge collection and construction, it also depends on a fixed reality that relies on the observer refusing to come close to understanding the complexity of Indigenous people and their experiences.

Concepts of ourselves, each other, and the landscapes and identities we share are played out locally and have profound implications for co-management agreements. One of the central principles of co-management is that it enables local resource-users to be part of, and take responsibility for, environmental management decisions. Many researchers have produced examples supporting the notion that co-management 'works' because particular local-scale cultural, political and geographical dynamics can inform and improve government management outcomes and decision-making (Pinkerton, 1996; Berkes et al., 1991). Yet contrasting definitions of, and rights to, resources can mean that reconciliation is difficult. As outlined above, Indigenous and non-Indigenous notions of group identity and environmental stewardship authority stem from different knowledge systems and modes of communication based on contrasting cultural values and beliefs. This conflict also reflects complex human and human-environment relationships that have been influenced by past, shared experiences. This dynamic is pivotal to an understanding of current challenges.

Geographers have recently explored the concept of hybridity to analyse this landscape and identity dynamic (Gregory, 1994; Whatmore, 1999). Hybridity provides a useful conceptual tool to rethink the rigid boundaries between us/other, civilised/savage, colonised/ coloniser and so on. Instead, researchers have recognised a myriad of social groups and 
meanings that shape and are shaped by relationships with place. The result, as Whatmore $(1999,26)$ has argued in relation to hybrid geographies, enables a form of inquiry that emphasises the agency of landscape in the analysis of social and human-environment relations:

[Hybridity] is concerned with studying the living rather than abstract spaces of social life, configured by numerous, interconnected agents - variously composed of biological, mechanical and habitual properties and collective capabilities — within which people are differently and plurally articulated.

Some authors have concentrated on hybrid social relations that are formed and impact upon land allocation and management decisions. Anderson (1998) has shown how Sydney's Redfern Aboriginal housing block and the Chinatowns of Melbourne and New York reflect the 'multiplicity and mobility' of urban areas which have been formed by complex and often contradictory racial and class-based groups. Banks (1997) highlighted the complexity of the relationship between a multi-national mining company and the local community of Papua New Guinea's Pogera valley. As Banks (1997) has argued, it is not adequate to examine the tensions and alliances inherent within resource development agreements simply in terms of the power-differentiated positionings of majority and minority interest groups. Instead, he found company and community relationships varied in type, intensity, direction, degree and duration.

Hybridity has also been used to explain how the past continues to influence modern experiences and landscapes. Jacobs (1995) connects ideas of colonial power and decolonisation in a range of metropolitan settings to show how European spatial practices continue to delineate and disempower Indigenous landscapes in Australian cities. Gregory (1994, 167-205) also utilises hybridity to analyse the complex historical geographies of colonialism and to guide his discussion of post-colonialism.
Not only has this area of scholarship analysed the complexity of social relations and experiences, it has also tackled the contested meanings surrounding culture and nature. Willems-Braun (1997) has analysed how Eurocentric constructs of 'nature' penetrate environmental conflicts in British Columbia's (BC) Vancouver Island. He found that tropes of past colonial ideas authorised certain voices while simultaneously marginalising others in decisions about the fate and future of the 'natural' forests of Clayoquot Sound (WillemsBraun, 1997). Not only does this work on the various facets of hybridity help to clarify the multiple and dynamic guises of landscapes, it also emphasises how groups assert the power to translate their landscape interpretations into practice.

As a partnership that aims both to improve relations between Indigenous and nonIndigenous people and enhance sustainable development, the concept and practice of comanagement confront a complex myriad of nature/culture and power/identity relationships. Drawing on IMAs that have recently been negotiated for access, allocation and management of the Skeena River's salmon fishery, this paper draws on these concepts of hybridity to examine how both contested and negotiated meanings surrounding the identity of fishing groups and landscape affect fishery co-management partnerships. I question the appropriateness and utility of western management practices that impose unhelpful divisions between society and nature, and between Indigenous and non-Indigenous people as resource managers. Yet I also find that within the flexibility of IMAs, hybrid fisher groups are able to form and negotiate partnerships that start to resolve some of the injustices of the past and build innovative and equitable management arrangements into the future.

\section{Co-management and the fishery resource in the Skeena River Region}

The Skeena River region of North-west British Columbia includes the homeland territories of 
the Tsimshian, Gitxsan, Wet'suwet'en and Nat'oot'en Indigenous peoples, known in Canada as the First Nations (Figure 1). As with other First Nations in the North-west of British Columbia, the cumulative knowledge of the laws established by mythological ancestors is an essential element in the establishment and confirmation of ownership rights and management responsibilities. Clan ties link House Chiefs to common ancestors and heritage, and these are articulated in names, crests, songs or collections of sacred histories, and find expressions in the web of principles regulating resource use and allocation within the wider First Nation territory.

Mountainous terrains and enormous catchments abundant with aquatic species, in particular salmon, provided a unique geographical setting which affected the different ways in which fur traders, missionaries, colonists and salmon fishers and cannery operators have engaged with the North-west region (Robinson 1999; Tennant, 1990). As the commercial fishing industry grew, tensions amongst fishers and between fishers and the Federal Department of Fisheries and Oceans (DFO) increased. Introduced management policies and plans failed to recognise that local indigenous resource-users were part of, and took responsibility for, management decisions. Instead DFO assumed that fisheries were ungoverned open-access resources which required government-formulated and imposed regulations.

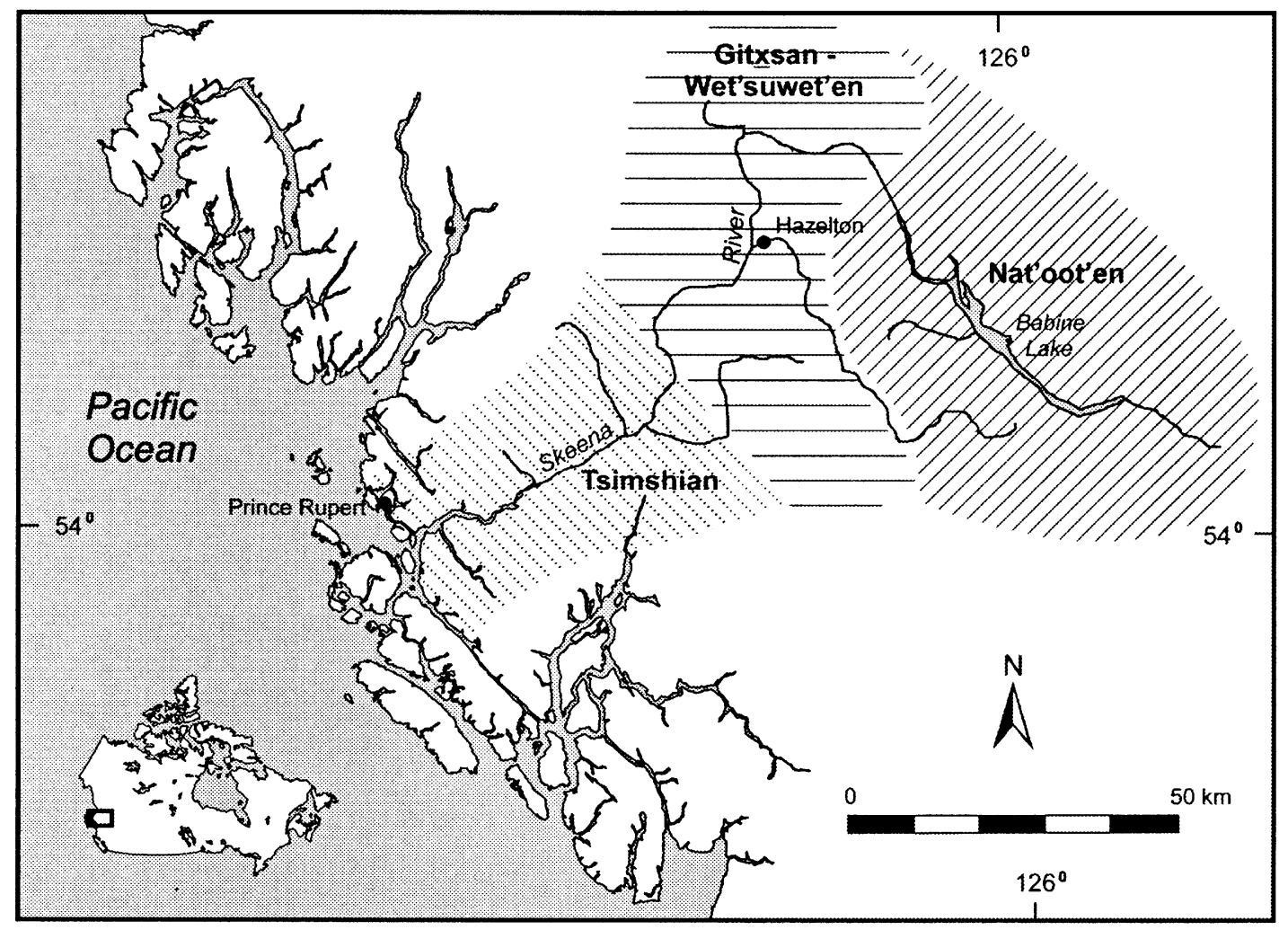

Figure 1 Approximate locations of territories of the Skeena's First Nation communities. 
As these facets of colonialism were imposed on their lives and lands, Indigenous communities began to struggle to have rights to their homeland territories and resources recognised and protected. Their concerns were occasionally transmitted through interpreters, expressed in local encounters with resident missionaries, fishers and other colonists, or lodged as native title claims in the courts. But First Nation voices and activities all displayed two recurrent and resilient themes. First Nations have always been willing to share their resources, but not to alienate their rights to them and thereby lose control over resource management and use. They also remain firm on the need to negotiate regional landscapes and relationships that recognise their communal property regimes and ensure their cultural survival.

The dynamic history of cultural and environmental frontier interactions is reflected in the present North-west region which is now shared and used by a number of Indigenous and non-Indigenous interests and communities. Local people of both Indigenous and nonIndigenous descent hold and cherish their distinct identities, but they also share notions about themselves as 'northern folk' who are connected through work, marriage and social relationships in closely knit communities within this fairly remote region.

In recent years, key developments in BC and in the Skeena River region have provided new prospects for First Nations to gain recognition of their native title rights. These developments include a greater role in resource use and management decision-making. Key court cases have included the 1990 Sparrow decision in which the priority and continuity of First Nation rights, in this case the rights to fishery resources, were affirmed and reinforced by the Canadian Constitution (Regina v Sparrow (1990) 1 SCR). More recently, the 1997 Delgamuukw decision supported the Gitxsan and Wet'suwet'en's right to choose how land and resources are to be used within their traditional territories (Delgamuukw $v$ British Columbia (1997) 3 SCR). As Usher
(1996) has argued, court decisions handed down thus far not only indicate that Indigenous people have rights to share the harvest and decisionmaking for environments and resources; they also recommend that governments recognise these rights within co-management arrangements.

Both the Canadian and Provincial BC governments have agreed to negotiate comprehensive claim settlements with First Nation communities. First Nations from North-west BC have all filed formal comprehensive claims for their traditional territories, while native title cases continue to be lodged and appealed in the courts. The salmon fishery has been central to native title negotiations. Although resource conservation remains a key factor on which to base fishery policy recommendations, First Nations are aware that actual decisions regarding the resource involved economic, political and social choices (Newell, 1993). In whose interests conservation effects were designed, and at whose expense, remain critical questions.

In 1981 the Gitxsansan and Wet'suwet'en people presented a proposal to the Pearse Pacific Fisheries Commission, a body established to produce various recommendations that would encourage more sustainable and equitable management of the fishery resource (Pearse, 1982; Morell, 1989). The proposal called for co-management dialogue and outcomes to be 'based on the principle that the hereditary House Chiefs must have the final authority and responsibility for resource management within their territories' (Pearse 1982, 160). While recognising that their community management system would need to be coordinated with other Indigenous and nonIndigenous authorities, the Gitxsan and Wet'suwet'en remained emphatic that they participate as equals in decisions about their country.

Several steps were taken to achieve the goals outlined in the Gitxsansan-Wet'suwet'en proposal. The Gitxsansan and Wet'suwet'en established a fishery agency in 1986 to provide 
a mechanism through which their fisheries management proposal could be negotiated and developed (Cassidy and Dale, 1988, 52-53). Various government schemes that had been introduced to enhance stream habitats, and to prepare Indigenous people for the management of the fishery resource, were utilised to train local First Nation people. The GitxsansanWet'suwet'en also identified some key issues that divided non-Indigenous and Indigenous laws and approaches. Government efforts were found to be directed at optimising the coastal harvest to the detriment of inland fishers and the resource base. DFO failed to acknowledge the authority of Indigenous resource owners and decision-makers. The regulation over First Nation's rights to sell and trade fish also failed to recognise the economic aspects of Gitxsansan and Wet'suwet'en native rights.

Eventually, alliances between the Gitxsansan, Wet'suwet'en, Tsimshian and Nat'oot'en First Nation communities proposed the creation of a community management arrangement asserting First Nation authority for the entire Skeena River catchment, based on the principles offered by the fishery proposal. Bob Hill, President of the Tsimshian Tribal Council, explained the underlying incentive:

We [First Nations] sat down together to form a framework upon which our distinct and shared native title rights for the fish could cooperatively manage the fisheries within the entire Skeena River catchment. Not only did this strengthen our position to negotiate how native title rights could work with other fishery interests and management agencies in the area ... it also made sense in our goals to sustain the fishery resource (fieldwork interview, 10/12/1997).

Under a Memorandum of Understanding (MoU) signed in February 1990, each First Nation committed itself to four principles of 'balanced respect'. First, each recognised the native title right to fish for social, ceremonial and economic purposes; second, each acknowledged that it continued to depend on the fisheries resource as a mainstay of economic, social and cultural well-being; third, it was agreed that the right to fish superseded all non-Indigenous fishing interests and would only be limited by the need for proper conservation of threatened fish stocks; and fourth that, as rightful 'Guardians', each was obliged to protect, conserve and harvest the fishery resource 'according to traditional law' (SFC (Skeena Fisheries Commission) files, 1990).

The Skeena Fisheries Commission was established to achieve the vision expressed in the MoU. The Commission's goal was to promote co-operation between First Nation and other fishers, and to work towards selfgovernance and economic self-sufficiency (SFC files, 1990). As the hereditary Chiefs emphasised, the Skeena Fisheries Commission would not only provide an important avenue to assert and apply native title and management on the Skeena River, it would also prevent what they considered to be unchecked destruction and mismanagement of their homeland territories. As an alternative, First Nations offered an organisation which recognises that equal partnerships can ensure that distinctive management approaches are respected and coordinated: among communities of each First Nation; between First Nations on the Skeena and neighbouring First Nations, and between First Nations, Canada, Provincial governments and the fishing industry.

Two key developments have affected the nonIndigenous fishery and government reception of the Skeena Fisheries Commission initiative. First, the extent and nature of native title rights continue to be tested in the courts. Yet increasingly the courts are recommending that formal and interim agreements between resource users and government departments will provide more fruitful results than continued litigation. Currently there are numerous interim co-management agreements in place along the BC coastline, including the DFO's (Department of Fisheries and Oceans) Aboriginal Fisheries Strategy. Details of the Aboriginal Fisheries Strategy have been discussed critically 
Table I Number of Indigenous and non-Indigenous commercial salmon fishing licences, 1995-1999. (Note: For further statistics for fish landings, licence numbers and types, economic value and quotas for all commercial fish harvested in BC and Canada, see DFO, 2000).

\begin{tabular}{|lrrrr|}
\hline Salmon fishery & 1995 & 1996 & 1997 & 1998 \\
\hline First Nation (Gillnet) & 505 & 436 & 436 & 421 \\
First Nation (Seine) & 65 & 57 & 56 & 54 \\
Nothern Native Fishing Corp. & 254 & 254 & 253 & 253 \\
Communal & 3 & 35 & 73 & 64 \\
& & & 818 & 792 \\
Total First Nation owned fishing licences & 827 & 782 & 2377 & 2324 \\
Non-Indigenous (Gillnet \& Troll) & 3064 & 2381 & 432 & 388 \\
Non-Indigenous (Seine) & 471 & 432 & 2809 & 2712 \\
Total non-Indigenous owned fishing licenses & 3535 & 2813 & & 3505 \\
& & & 3628 & \\
\hline
\end{tabular}

elsewhere (Robinson, 1998). Essentially, the Strategy provides each First Nation community with specific fish harvesting quotas and, in some cases, the right to sell fish. Funding and training programs dedicated to increase First Nation participation in fishery management have also been established.

Prior to the Aboriginal Fisheries Strategy, alliances had already been forged between First Nation, commercial and sport fishers on some key issues of common concern. In particular, all parties were anxious about the reduction in fish harvest levels, and all agreed on the need for new and more active involvement in fishery management decisions. Co-operation between Indigenous and non-Indigenous fishers was deemed particularly necessary when DFO issued a policy in 1991 that committed fishers to a $50 \%$ reduction in the harvest of salmon over the next three years. In 1996, more restrictions on fishing were imposed when F. Mifflin, the Minister responsible for the DFO, announced that there were too many fishers competing for weakened salmon stocks, putting the stocks at risk, and introduced a comprehensive strategy for the salmon resource. The strategy included measures to reduce the commercial salmon fleet by $50 \%$ over several years, an $\$ 80$ million licence retirement program, a reduction in fish harvest levels, the adoption of more stock- selective fishing practices, and the encouragement of industries that are less dependent on salmon (DFO, 1999).

British Columbia's commercial fishing sector supports a key primary industry with an estimated worth of approximately $\$ 400$ million; First Nation people hold about $20 \%$ of the commercial salmon licences (Table I). Sport and recreational fishing also play an important role in the tourism industry. On average, the commercial fishery is currently allocated around $94 \%$ of the salmon stock, the sports fishery $3 \%$, and the 'Aboriginal fishery' the remaining 3\% (DFO, 1995, 15; DFO 1999). Changes imposed by DFO have attracted widespread criticism, particularly from northern communities who consider them designed to expand the large vessel fleet and eliminate small boats.

As a result of these wider political, legal and resource management developments, DFO negotiated a Skeena Watershed Agreement with the Skeena River First Nations under the Aboriginal Fisheries Strategy program. Under this agreement, committees and subcommittees for policy planning and monitoring/enforcement have been set up to provide a co-ordinated approach to the conservation and management of fisheries allocated to Skeena First Nation communities within the catchment area. The Watershed Agreement provides 'contiguous 
Aboriginal jurisdiction to enforce the Fisheries Act, from the sea zone to the headwaters of the Skeena catchment' through the training and employment of Aboriginal Fishery Guardians who work under the co-operative guidance of the Skeena Fisheries Commission, Hereditary Chiefs and the DFO (SFC, 1995a). Guardian duties include assessments of fish stocks, provision of fish catch information to the Skeena Fisheries Commission and the DFO, monitoring fish landing sites, and carrying out patrols on the land and water to monitor fishing and habitat activities. As the Skeena Fisheries Commission noted in its 1995 annual report, such agreements mark important progress towards First Nation goals of equitable cogovernance:

We have found that by working together in an interest-based forum, the perceived problems of jurisdictional exclusivity have been supplanted ... [through] this practical working relationship between federal and First Nation jurisdictions. As it stands now these jurisdictions are seamless and noncompetitive. ... The movement toward the full recognition and acceptance of the Aboriginal right in its rightful place is subtle and incremental. ... So we see that the issue of Aboriginal jurisdiction has not, on the Skeena, come up as an exercise in drawing lines in the sand and the inflammation of third party fears. We are way past that here now (SFC files, 1995b, 6).

The agreement has also enabled the Skeena First Nations to have more control over fish allocated for food, social and ceremonial purposes and fish allocated for commercial use - both categories are now administered under a communal licence. Each First Nation is entitled to harvest and sell a third of fish allocated under a surplus licence, provided fish are landed at or transferred to one of the three designated landing sites along the Skeena River. All fish landed are then inspected and counted by a DFO officer and First Nation Fishery Guardian. It is a unique operation. Traditional methods of selective fishing have been enforced for fish taken for commercial sale, to ensure that abundant species are targeted and weaker stocks preserved (SFC files, 1995b). All vessels fishing for allocated catches are accompanied by an appropriate First Nation Elder to ensure that protocols are observed.

Profits from the sale of commercial fish are returned to the Skeena Watershed Trust, established under the control of the Skeena Fisheries Commission. This provides funding for First Nation employment, stream restoration, community meetings and training programs. All Skeena First Nations have also negotiated an inter-tribal trade agreement. If seasonal conditions result in allocated fish going beyond traditional territories before harvest, a First Nation can 'sell off' its allocation to an upriver First Nation. Alternatively, any First Nation can invite other First Nation fishers to enter its territory to catch allocated fish, provided an Elder for that fishing area or site is on board.

Meanwhile, meetings between North-west coast Indigenous and non-Indigenous fishers have continued, often in the absence of government authorities - 'to talk fish and to talk to each other', as commercial fisherman Des Nobles puts it - and to work out how they could co-operatively make the North-west a more productive region (Gallaugher, 1996). Prompted by conservation concerns expressed by local Indigenous and non-Indigenous parties fishing the Skeena, fishers, the DFO and the Province (responsible for the management of the sport-fished steelhead) agreed to work together to address the general fish conservation and allocation issue. In 1992, a MoU was signed between all the parties to form a Skeena Watershed Committee (Figure 2). The Committee, made up of five equal partners representing each group, aims to determine management, protection and allocation of fish under consensus arrangements, to maintain open dialogue on the health and use of the fishery resource, and to work towards an integrated catchment management process. As the $\mathrm{MoU}$ states: 


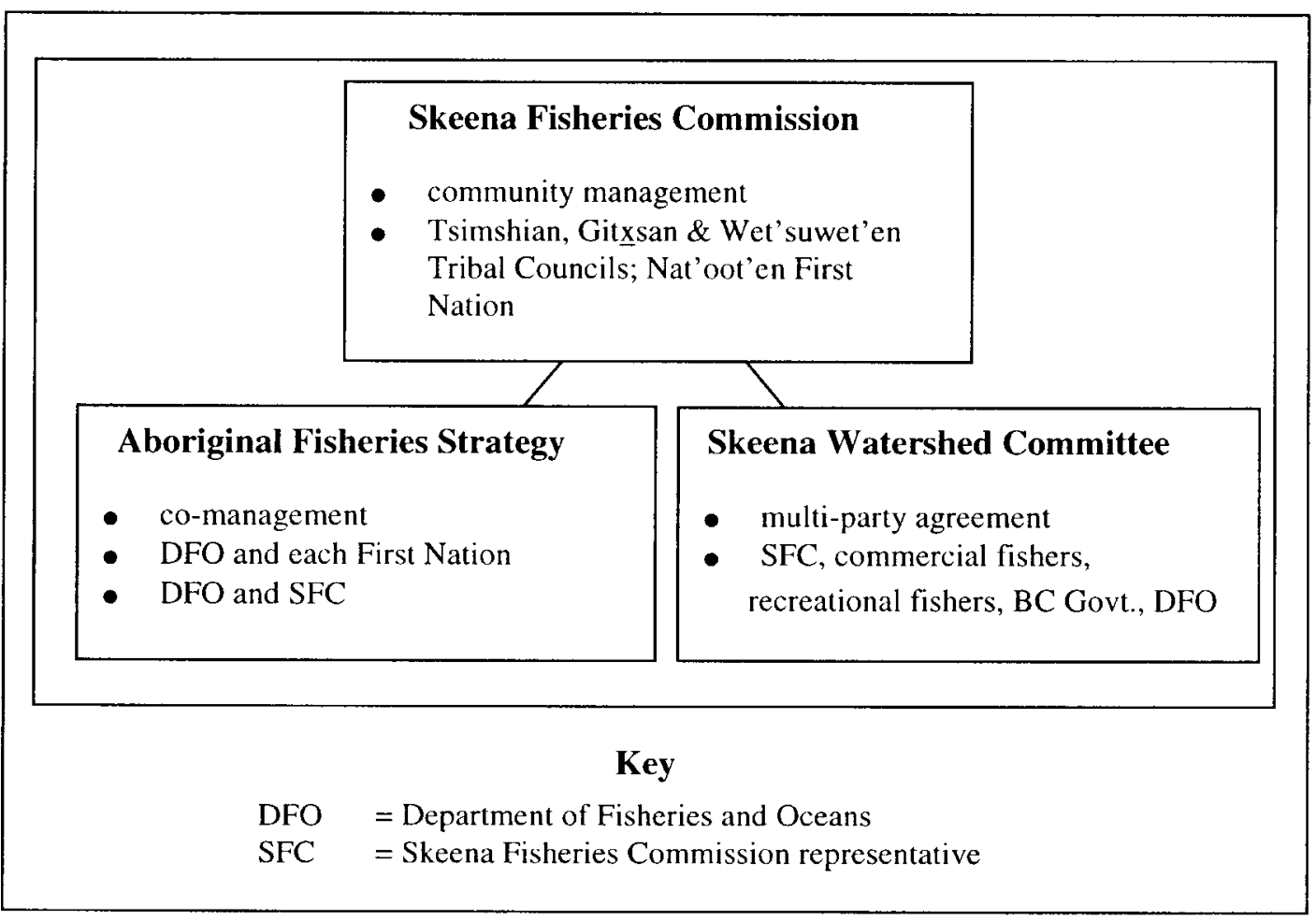

Figure 2 Community, co-management and multi-party agreements operating on the Skeena River.

Fisheries management problems in the Skeena Watershed require 'made in the North' solutions that accurately reflect resource conservation and the wellbeing of individual residents and communities .... The Committee will encourage high environmental ethics and integrated resource management as the primary means to achieve sustainable fisheries .... The Committee will recognize and respect the constitutional rights of Aboriginal people ... . This agreement is without prejudice to these rights (DFO, 1992).

Aware that First Nation communities are the last to access fish along the migration path of salmon to their spawning ground, and that many of their own members are commercial fishers, the Skeena Fisheries Commission has good reason to be involved as an equal partner. Even so, it ensures that the mandate remains clear:

[First Nations] are committed to the SWC [Skeena Watershed Committee] process and will support the process with effort, ideas and advocacy ... the Aboriginal right to the resource can be interpreted in many ways. To us it means the right to have sufficient say in the management of the resource so that our future is secure. Our security is directly linked to that of the fish. Seen from a community-based perspective, all interests in the Skeena can also have the right to security. In order to achieve it they must take on the management responsibility (Skeena Watershed Committee, 1996, 17-18).

Hybrid social and human-salmon relationships affect the network of partnerships that now exist 
within the Skeena River catchment (Figure 3). Co-management offers a process (or 'network') where conflicting and shared interests in salmon can come together to shape, or be shaped by, relationships with the Skeena River (Murdoch and Marsden, 1995; Whatmore and Boucher, 1993). The recognition of the complexity and agency of this network helps to clarify how certain representations concerning salmon can be made while other viewpoints cannot. For example, divisions between 'Settlers' and 'First Nations' continue to be simplified within Canada's wider political and popular discourse which affects, but does not always reflect, the reality or diversity of the Skeena River community. The wider debate about the Aboriginal right to manage and sell fish, for instance, is played out and re-interpreted to adapt to the Skeena River's watershed plans and activities. Meanwhile the roles of the Skeena Fisheries Commission or the Watershed Committee following settlement of comprehensive claims are still being negotiated. The completion of comprehensive claim negotiations along other areas of BC's coast is also expected to affect conservation decisions and fish allocations for all parties on the Skeena. Members of the Watershed Committee recognise that the flexible interplay of fisher groups and management priorities will be more difficult within formal agreements. Nevertheless all parties have committed to continue working together after native title claims have been resolved in an effort to conserve and improve the salmon resource (Skeena Watershed Committee, 1996).

Although the contestation over salmon management activities and decisions suggests that problematic power imbalance exists between fishers operating within the Skeena River catchment, it is also clear that fisher group alliances are complicated and restless. Conflict does exist within and between First Nation and non-Indigenous fisher communities. Disagreement about the appropriate delegation of political and resource management authority, economic benefits, and environmental responsibility for the salmon species are key issues that strain dialogue within the First Nation Skeena Fisheries Commission. Different interests within the commercial and recreational fishing sectors also affect the network of social relations and relationships with the Skeena and salmon natur(al)e (resource). Conservation agendas and plans negotiated by the Watershed Committee have also been subject to changes dictated by the powerful forces of international fishing industries and markets. This influences the DFO's shifting support for some of the negotiated projects and decisions and prompts people living in the Skeena River catchment to form 'made in the north'

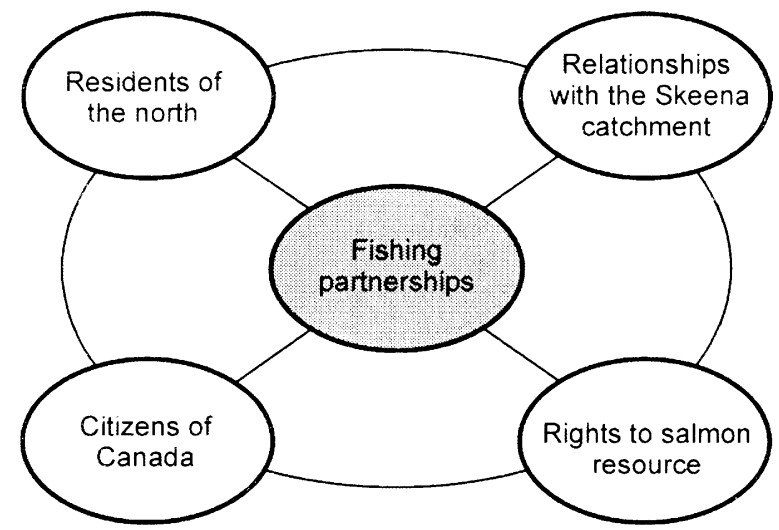

Figure 3 Hybrid social and human-environment relations that affect the network of salmon co-management partnerships on BC's Skeena River. 
solutions that seek to ensure that their rights as citizens and fishers of Canada are protected.

Skeena River fisherfolk do link their identity to the salmon in different and complex ways, but their commitment to salmon partnerships has promoted new hybrid forms of identity to be developed and innovative management activities and approaches to occur. Already the shift of fishing effort to upriver locations, conservation efforts undertaken by the Skeena Fisheries Commission, and the collective responsibility taken on by fish harvesters, has seen a significant increase in the mixed stock of the fishery and also in the total harvest within the Skeena system (Pinkerton, 1996; SFC, 1995). The Commission and DFO also both agree that co-operative partnerships have developed and strengthened. As Bob Hill from the Tsimshian Tribal Office explained, such agreements reflect a growing shift in fishery management that is controlled by both DFO and Skeena First Nation priorities and agendas. 'These agreements are signs that [First Nation] goals for fishery management on the Skeena are slowly being achieved ... two systems of government working as co-managers — that's the aim' (fieldwork interview, 10/12/1997).

\section{Hybridity and co-management on the Skeena River lessons for Australia}

Resource managers and users in Australia have increasingly shown interest in Canada's experience with regional agreements in the hope that they will offer some guidance for the resolution of local native title claims. Of course, as O'Faircheallaigh $(2000,2)$ rightly argues, 'given the great variety of contexts in which Indigenous people find themselves, the range of projects about which Indigenous groups have to negotiate and the diverse objectives they may wish to pursue', a single 'best practice' model is neither achievable nor desirable. Obviously, but importantly, the cultural, historical and physical geography of Indigneous people's country is both locally and regionally unique. A salmon is not a turtle or dugong, nor is it a silica or bauxite mine. Co-management agreements must engage with the agency of local place and community to ensure that partnerships can be sensitive to the network of social and human-environment relationships that surround the management of a given resource.

Yet some key aspects of the Skeena River experience can provide Australians with useful starting points for the encouragement of comanagement dialogue which reflects the essence of native title claims. Hybrid identities and relations with the natural environment converge within co-management partnerships, and reflect distinct and negotiated concepts of conservation and rights to the resource. The result is a myriad of social and human-environment relationships that can have both positive and negative effects on the ongoing process of making regional agreements.

On the positive side, resource use conflict, degradation of habitat and the mutual desire to conserve resources can provide the common ground for local community members to coordinate their distinct resource interests and management approaches. Fishers on the Skeena have found that agreements based on resource conservation/development issues are easier to achieve than the negotiation of the content and extent of native title claims. Indigenous communities in Australia are also trying to ensure that native law and responsibility provide the template for co-management dialogue. In recent years, vital alliances between Australia's Indigenous and non-Indigenous community members have also started to form in an effort to ensure that management and development imperatives also include conservation and sustainability objectives (Robinson, 1999; Sharp, 1998). These recent local efforts to establish cross-cultural management partnerships around shared Indigenous and other notions of place offer insights into how sustainable co-existence might be achieved.

A central issue facing Indigenous people in Canada and Australia is the challenge of how country is looked after and who is involved. Government initiatives in Canada, such as the comprehensive claims policy and the Aboriginal Fisheries Strategy, support legal decisions which clearly state that conservation and development 
activities must be achieved in the context of sustainable use and priority for Indigenous people's rights. The challenge in Australia is similar (Robinson and Mercer, 2000). Although Australian governments continue to be a reluctant partner in the native title claim process, aspects of co-management policy and practice operating on the Skeena River might provide Australia's Indigenous people and communities with some productive leads.

In particular, fishers on the Skeena have developed some innovative approaches to the application of reconciliation within negotiated comanagement partnerships. Salmon-fishing IMAs negotiated thus far originate from and reflect the unique hybridity that exists between North-west fishers, amongst First Nation groups, and between fishers and the DFO. Flexibility within these agreements allows the process and outcomes of management decisions to be negotiated and renegotiated locally. Issues that are difficult to reconcile (such as the formal recognition of native title) are put to one side to allow fisherfolk to build new relationships as co-partners.

Yet as Scarce (1999) has discussed in some detail, resources such as salmon continue to be a product of a nature that has been filtered through social processes. Political agendas and scientific discourses both act to ensure that the dominant construction of nature as common property resources, objects of biology or economic commodities, is sanctioned and legitimised. These concepts ignore the complex historical geographies and life histories with Canada and Australia and erase Indigenous people's understandings of their country, which in turn deny them the power to direct present and future management decision-making.

Of course there are also important differences between IMAs and formal regional agreements. Rather than redressing and implementing the regime of authority that native title confers, comanagement on the Skeena River has focused on access and defined control over the salmon resource. Undefined authority can translate into undefined responsibility, including government commitment to support and help interim- measures programs. Indigenous communities in Canada and Australia point to uneven (or nil) control over some areas and resources within their homeland territories, which remain subject to separate government jurisdictions and specific government agendas. Ultimately, the unfinished business of native property rights, including rights to use and manage resources, will have to be resolved.

The constant interplay between both positive and negative aspects of hybrid identities and landscapes within the Skeena River catchment provides useful insights into the wider question surrounding the recognition of native title rights and management responsibilities in both countries. What aspects of co-management encourage or hinder equitable cross-cultural dialogue? Shared Indigenous and nonIndigenous notions of this unique situation reflect the product of an elaborate web of distinct, common and continuing perspectives and experiences. Organisations such as the Skeena Fisheries Commission and Watershed Committee reflect this hybridity, and also offer some innovative ways to establish common ground between Indigenous and non-Indigenous people who have taken on the challenge of negotiating agreement by means of open and equitable exchanges of views.

\section{Conclusions}

The negotiation of native title rights is a key site of both hope and contestation in Canada and Australia. In the past, government legislation in both countries related to resource rights and allocation, usually benefited the dominant, nonIndigenous majority without Indigenous people's input, regardless of the effects on Indigenous country, rights and livelihoods. Only in recent decades are efforts being made to establish workable and long-lasting agreements that include Indigenous people. These include the introduction of policies and legislation that specifically deal with Indigenous rights and environmental management issues. The process is still in its early phases, but some criteria and frameworks for permanent and binding local 
and regional co-management agreements have been established.

Criteria to achieve workable and meaningful regional agreements will have to take into account the particular historical, cultural and geographical situations that affect the ways in which distinct and hybrid groups translate their views of resources (such as salmon) into the network of co-management partnerships and practices. Jacobs $(1995,8)$ finds that hybrid spaces and places in Australian cities reveal a 'disruptive network dynamic where colonised peoples are appropriated by dominant cultures', while Whatmore and Boucher (1993) show how networks of co-existence can empower western viewpoints over those of minority groups. Unfortunately, some legacies of the past impede the process of reconciliation. For example, IMAs do not recognise the extent of Skeena River First Nation's cultural land, river and seascapes, or fully recognise First Nation regimes of resource management. Although an essential component of native title is the notion that Indigenous resource management rights express distinct local Indigenous legal systems, government agencies like DFO are still reluctant to acknowledge or translate these rights into pluralistic co-management agreements.

Yet efforts made by Indigenous and nonIndigenous communities who share BC's Skeena River also offer innovative ways to establish new management regimes that start to recognise and engage with native title rights and management responsibilities. Canadian governments have responded to these initiatives by sharing management responsibilities with local communities in the region. As a result, partnerships have been created that are worthy of investigation for the Australian context. The presence of valuable resources, notably BC's lucrative Pacific commercial fishing industry, has probably also induced governments to resolve native title issues. Despite the fact that the cultural and physical geography of $\mathrm{BC}$ is both locally and regionally special, aspects of co-management partnerships achieved on the Skeena River might provide Indigenous and non-Indigenous resource users in Australia with some productive leads. In particular, new regimes developed by co-management show potential for offering a network where hybrid identities, landscapes and agreements promote, rather than disrupt, the ethics and principles underpinning Indigenous people's rights and responsibilities to their country.

Correspondence: Dr Cathy Robinson, School of Geography and Oceanography, University College, UNSW, Australian Defence Force Academy, Canberra, ACT 2600, Australia. Email: c.robinson@adfa.edu.au

\section{ACKNOWLEDGMENTS}

This article is based on doctoral research on the development of co-management in Australia's Northern Territory and in British Columbia, Canada. A special thanks to my dedicated supervisors, Professor Joe Powell (Monash) and Dr Deborah Bird Rose (ANU), who have helped my research in so many ways. Access to files from the Department of Fisheries and Oceans (British Columbia, Northern Region) and the Skeena Fisheries Commission was also appreciated. Thanks are also due to Dave Paull who offered insightful comments on a draft, and Ian McCredie who improved the Figures. Finally I wish to acknowledge fellow colleagues who provided constructive feedback when I delivered this article as a paper to the 1999 Institute of Australian Geographers conference in Sydney.

\section{REFERENCES}

Anderson, K., 1995: Culture and nature at the Adelaide Zoo: at the frontiers of 'human' geography. Transactions, Institute of British Geographers 20, 275-294.

Anderson, K., 1998: Sites of difference. Beyond a cultural politics of race polarity. In Fincher, R. and Jacobs, J.M. (eds) Cities of Difference. The Guilford Press, New York, 201-225.

Banks, G., 1997: Mountains of desire. Mining company and Indigenous community at the Pogera gold mine, Papua New Guinea. Unpublished PhD Thesis, The Australian National University, Canberra.

Berkes, F., George, P., and Preston, R., 1991: Co-management: The evolution of the theory and practice of the joint administration of living resources. Alternatives 18, 128.

Cassidy, F. and Dale, N., 1988: After Native Land Claims? The Implications of Comprehensive Claims Settlements for Natural Resources in British Columbia. Oolicahn Books and the Institute of Research on Public Policy, Lantzville.

DFO (Department of Fisheries and Oceans), 1992: Memorandum of Understanding - Skeena Watershed Committee, Prince Rupert.

DFO, 1995: Aboriginal Fisheries Strategy Deskbook. Pacific Region, Government Printer, Vancouver. 
DFO, 1999: An Allocation Policy for Pacific Salmon. A New Direction. Government Printer, Vancouver.

DFO, 2000: DFO statistical services @ http://www. ncr.dfo.ca/communic/statistics/stat_e.htm.

Gallaugher, P., 1996: Coastal communities: Taking action, a year of dialogue along the British Columbia coast. Proceeding of the Coastal Community Network Forum. Simon Fraser University, Vancouver, 5-35.

Gregory, D., 1994: Geographical Imagination. Blackwell Publishers, Oxford.

Ingold, T., 1994: From trust to domination. The alternative history of human-animal relations. In Manning, A. and Serpell, J. (eds) Animals and Human Society: Changing Perpectives. Routledge, New York, 1-22.

Jacobs, J.M. 1995: Edge of Empire. Routledge, London.

Morell, M., 1989: The struggle to integrate traditional Indian systems and state management in the salmon fisheries of the Skeena river, British Columbia. In Pinkerton, E.W. (ed) Co-operative Management of Local Fisheries: New Directions for Improved Management and Community Development. University of British Columbia Press, Vancouver, 231-48.

Murdoch, J. and Marsden, T., 1995: The spatialization of politics: local and national actor-spaces in environmental conflict. Transactions of the Institute of British Geographers 20, 368-380.

Newell, D., 1993: Tangled Webs of History. Indians and the Law in Canada's Pacific Coast Fisheries. University of Toronto Press, Toronto.

Notzke, C., 1995: A new perspective in Aboriginal natural resource management: co-management. Geoforum 26, 187-209.

O'Faircheallaigh, C., 2000: Negotiating Major Project Agreements: The 'Cape York Model'. Australian Institute of Aboriginal and Torres Strait Islander Studies. Research Discussion Paper no. 11, Aboriginal Studies Press, Canberra.

Pearse, P.H., 1982: Turning the Tide. A New Policy for Canada's Pacific Fisheries. Commission on Pacific Fisheries Policy, Department of Fisheries and Oceans, Vancouver.

Pinkerton, E., 1996: The contribution of watershed-based multi-party co-management agreements to dispute resolution: The Skeena Watershed Committee. Environments 23, 51-68.

Richardson, B.J., Craig, D. and Boer, B., 1994: Indigenous peoples and environmental management: a review of Canadian regional agreements and their potential application to Australia (parts 1 and 2). Environmental and Planning Law Journal 35, 21-33.

Robinson, C.J., 1998: Marine co-management arrangements with Indigenous peoples: issues and options. In Bliss, E. (ed.) Proceedings of the 2nd Joint Conference of the Institute of Australian Geographers and New Zealand Geographical Society. Conference Series no. 19, New Zealand Geographical Society, Massey University Printery, Palmerston North, 81-84.
Robinson, C.J., 1999: Indigenous-settler interactions on frontier coasts. The development of co-management in Australia's Northern Territory and in British Columbia, Canada. Unpublished $\mathrm{PhD}$ thesis, Monash University, Melbourne.

Robinson, C.J. and Mercer, D., 2000: Reconciliation in troubled waters? Australian oceans policy and offshore native title rights. Marine Policy 24, 349-360.

Rose, D.B., 1996: Nourishing Terrains. Australian Aboriginal Views of Landscape and Wilderness. Australian Heritage Commission, Canberra.

Scarce, R., 1999: Who - or what - is in control here? Understanding the social context of salmon biology. Society and Natural Resources 12, 763-776.

SFC (Skeena Fisheries Commission) files 1990: Skeena Fisheries Program. Proposal prepared by Skeena Fisheries Commission, representing the Gitxsan-Wet'suwet'en Chiefs, the Tsimshian Tribal Council, the Lake Babine Band and presented to the Department of Fisheries and Oceans, the Department of Indian Affairs and Northern Development, and the Department of Employment and Immigration, Ottawa.

SFC files, 1995a, Skeena Watershed Agreement between Department of Fisheries and Oceans and Skeena Fisheries Commission, Prince Rupert.

SFC files, 1995b: Final Report 1994/5. Hazleton.

Sharp, N., 1998: Handing on the right to fish: the law of the land and cross-cultural co-operation in a gulf community in Australia. Pacific Conservation Biology 4, 95-104.

Skeena Watershed Committee, 1996: Facing and Forming the Future. Report of the Skeena Watershed Committee meeting, Prince Rupert, 1920/1/1996.

Strang, V., 1997: Uncommon Ground. Cultural Landscapes and Environmental Values. Berg, Oxford.

Tennant, P., 1990: Aboriginal Peoples and Politics. The Indian Land Question in British Columbia, 1849-1989. University of British Columbia Press, Vancouver.

Usher, P.J., 1996: Contemporary Aboriginal Lands, Resources, and Environmental Regimes: Origins, Problems, and Prospects. Report for the Canadian Royal Commission on Aboriginal Peoples, Government Printer, Ottawa.

Whatmore, S., 1999: Hybrid geographies: Rethinking the 'human' in human geography. In Massey, D., Allen, J. and Sarre, P. (eds) Human Geography Today. Polity Press, Cambridge, 22-39.

Whatmore, S. and Boucher, S., 1993: Bargaining with nature: the discourse and practice of environmental planning gain. Transactions of the Institute of British Geographers 18, 166-178.

Willems-Braun, B., 1997: Buried epistemologies: the politics of nature in (post) colonial British Columbia. Annals of the Association of American Geographers 87, 3-31.

Young, E.A., 1999: Hunter-gatherer concepts of land and its ownership in remote Australia and North America. In Anderson, K. and Gale, F. (eds) Cultural Geographies, 2nd ed. Addison Wesley Longman, Melbourne, 319-38. 